\title{
Genetic variations in upland cotton (Gossypium hirsutum L.) for yield and fiber quality traits
}

\begin{abstract}
Cotton (Gossypium hirsutum L.) is one of the most important fiber and oilseed crop in family Malvaceae. Pakistan is 4th largest cotton producing countries but yield per acre is low with respect to other cotton producing countries. The aim of the study is to examine combining ability effects and gene action of yield and yield contributing traits in upland cotton. Four upland cotton genotypes i.e. MARVI, FH-458, MNH-996 and VH-333 were grown and crossed in full diallel mating design. Joint regression analysis revealed that data of all traits was fit for additive-dominance model and all the characters except fiber length were controlled by non-additive type of gene action following dominance and over dominance. As all the genotypes were significantly different. The genotype FH-458 showed best GCA effects fiber length. MARVI was found best general combiner for number fiber fineness while VH-333 was best general combiner for fiber strength. MNH-996 showed best general combining ability for average fiber strength. Among the F1 hybrids FH-458 $\times$ FH-458 showed good specific combining ability effects for fiber fineness, MARVI $\times$ FH-458 and FH-458 $\times$ MARVI for number of strength, FH-458 $\times$ MARVI for fiber length.
\end{abstract}

Volume 4 Issue 3 - 2020

\author{
Iffat Nazir,' Hafiz Zaid Mahmood, ${ }^{2}$ Tariq \\ Manzoor $\mathrm{khan}^{3}$ \\ 'Department of plant breeding and genetics, university of \\ agriculture Faisalabad, Pakistan \\ 2Department of microbiology, university of agriculture \\ Faisalabad, Pakistan \\ ${ }^{3}$ Department of plant breeding and genetics, university of \\ agriculture Faisalabad, Pakistan
}

Correspondence: Iffat Nazir, Department of plant breeding and genetics, university of agriculture Faisalabad, Pakistan, Email iffatnazir35@gmail.com

Received: June 04, 2020 | Published: June 16, 2020

\section{Introduction}

Cotton (Gossypium hirsutum L.) is one of important fiber and cash crop of Pakistan. Due to wide range of its importance, cotton also famous as white gold. In Gross Domestic Product (GDP), contribution of agriculture is 19.5 percent in Pakistan and provides sources of income to 42 percent population of rural areas. Cotton plays a vital role in Pakistan's economy and produces foreign exchange by exporting fiber and textile goods. Pakistan is the 4th larger cotton producing country and ranked $3 \mathrm{rd}$ in cotton consumption. Contribution of cotton is one percent in GDP and contributes about 5.2 percent in agriculture. The area under cotton cultivation during 2016-17 was 2.4 million hectares with a 14.2 percent marked decrease in the area against the area of 2.9 million hectares of the year 2015-16. During 2016-17 the production of cotton remained 10.671 million bales whereas during 2015-16 production of cotton was 9.917 million bales. ${ }^{1}$

Agriculture sector of Pakistan mainly depend on cotton crop. Fiber quality and seed cotton yield is low in Pakistan as compared to developed countries, so the improvement of fiber quality is the main economic goal. Diallel analysis will be helpful in selecting superior lines with significant genetic compliment. Additive gene action with higher GCA estimates and non-additive gene action with higher SCA estimates have potential role in the identification and selection of superior lines. ${ }^{2}$

Due to the importance and demand of cotton it is necessary to develop cotton varieties with high yield potential and fiber qualities. For this purpose it is necessarily to study the inheritance pattern of genes for various yield and fiber quality contributing traits which are helpful for the genetic improvement of available germplasm. It has been investigated that several traits inherited quantitatively are under the action of both additive and non-additive effects of gene. Using different selection and breeding methods considerable improvements have been made in yield of cotton and in the genetic composition of the cotton plant. $^{3}$

The Diallel method is an efficient crossing method that provides a base population with more genetic variation and helps the researchers to discover genetic variability present in various agronomic traits. ${ }^{4}$ Researchers commonly used this method to study the inheritance pattern of genetic variations in various plant characters. ${ }^{5,6}$ This analysis provides information about gene action, general combining ability (GCA) and specific combining ability (SCA). In addition to this combining ability analysis also help in recognizing desirable combination and opportunity of exploiting heterosis for improvement of cotton yield and fiber quality traits. ${ }^{5}$

Aims of study, is designed to discover the genetic action and heritability estimates in four parents and their $12 \mathrm{~F} 1$ hybrids. The information explored from this study helpful for the future researchers working on the improvement of cotton for high yield and fiber quality.

\section{Material and methods}

The study was conducted to find out the combining ability analysis (GCA,SCA and RCA) and the gene action in the Department of Plant Breeding and Genetics, University of Agriculture Faisalabad. The material comprised four upland cotton genotypes viz., MARVI, FH458, MNH-996 and VH-333 of upland cotton. These genotypes will be grown in the pots and placed in the green house during November 2016. The required environmental conditions (temperature, humidity and sunlight) were provided in the green house. When the plants started to flower hand emasculation was carried out in evening and following morning pollination was done. At the time of blooming all the genotypes were crossed in all possible combinations in diallel fashion to produce the F 0 seeds. Temperature and light in the green house were maintained $250 \mathrm{C}$ day and $300 \mathrm{C}$ night using steam and electric heaters. All possible precautionary measures will be taken to protect the plants from all biotic and abiotic stresses.

The list of parents and their direct and indirect crosses is given below:

Parents:

MARVI

FH-458 


\section{MNH-996}

VH-333

Direct crosses:

Marvi $\times$ FH-456

Marvi $\times$ MNH-996

Marvi $\times$ VH-333

FH-458 $\times$ MNH-996

FH-458 $\times$ VH-333

MNH-996 × VH-333

Indirect crosses:

FH-456 $\times$ Marvi

MNH-996 × Marvi

VH-333 $\times$ Marvi

MNH-996 $\times$ FH-458

VH-333× FH-458

VH-333 $\times$ MNH-996

\section{Fiber characters}

Fiber characters like a clean sample of lint was obtained from bolls of each selected plant. Fiber characteristics (Staple length, fiber strength, fiber finness and fiber uniformity ratio) were recorded from these samples using Ustar HVI 900 S.A. in the Department of Fiber Technology, University of Agriculture, Faisalabad. The computerized instrument recorded staple length $(\mathrm{mm})$, fiber strength $(\mathrm{g} / \mathrm{tex})$, fiber fineness ( $\mu \mathrm{g} / \mathrm{inch})$ and fiber uniformity ratio according to standard. It measures the fiber characters with in a quick period of time according to the international trading standards. Mean genotypic values of these characters were then calculated.

\section{Fiber length $(\mathrm{mm})$}

Staple length is the length of fibers in millimeters $(\mathrm{mm})$.

\section{Fiber fineness $(\mu \mathrm{g} / \mathrm{inch})$}

Micronaire is the fineness of the fibers expressed in $\mu \mathrm{g} / \mathrm{inch}$.

\section{Fiber strength (g/tex)}

Fiber strength is the tensile strength of fibre in g/tex.

\section{Statistical analysis}

The recorded data was subjected to analysis of variance ${ }^{7}$ in order to determine the genotypic differences for selected traits. Traits showing significant differences were further analyzed diallel analysis following Hayman and Jinks. ${ }^{6,8}$

\section{Analysis of gene action}

Several genetic crossing designs have been used in past to identify the genetic and environmental control of the quantitative traits in plants. Diallel crossing design is most common and popular crossing design for crop improvement. It involves the crossing of set of parents in all possible combinations to develop Fl hybrids. It is used to create variation and to investigate the genetic parameters controlling the inheritance of traits under study. Data were then Subjected to analysis of gene action following diallel analysis technique developed by Hayman and Jinks. ${ }^{6,8}$ This is also known as graphical technique which provides correct and more accurate information about mechanism of gene action of quantitative traits. The basic assumptions of this technique are:

1. Parents must be homozygous

2. Normal diploid segregation.

3. No reciprocal differences.

4. No linkage

5. No multiple allelism

6. No epistasis

Hayman ${ }^{6}$ formulated an easy way of extracting information from a diallel cross by plotting the covariance $(\mathrm{Wr})$ of each array against its variance $(\mathrm{Vr})$. The slope and position of regression line and thus fitted to array points, lying within parabola indicates a degree of dominance and presence of gene interaction. The position of array points on the regression line gave a measure of relative frequency of dominant and recessive alleles in an array. Diallel table were formulated by taking the means of direct and reciprocal crosses of F1 hybrids and were arranged in an array. The variance ( $\mathrm{Vr}$ ) of family mean with an array and covariances $(\mathrm{Wr})$ of array with parental means were calculated as

$$
\mathrm{Vr}=\frac{\sum \mathrm{Xi}^{2}-\left(\sum \mathrm{Xi}\right)^{2} / \mathrm{n}}{\mathrm{n}-1}
$$

Where ,

Vri $=$ Variance of the ith array.

$\sum \mathrm{Xi}^{2}=$ Sum of squares of ith array.

$\sum \mathrm{Xi}=$ Sum of ith array.

$\mathrm{n}=$ Number of observations.

Covariance of these means with non-recurrent parents mean was calculated by using following formula:

$$
\text { Wri }=\frac{\sum \mathrm{XiYi}-\left(\sum \mathrm{Xi}\right)\left(\sum \mathrm{Yi}\right) / \mathrm{n}}{\mathrm{n}-1}
$$

Where,

Wri $=$ Covariance of the ith array.

$\sum \mathrm{Xi}=$ Sum of the ith array.

$\sum \mathrm{Yi}=$ Sum of the parental mean.

$\sum \mathrm{XiYi}=$ Sum of the product of ith array and parental means.

$\mathrm{n}=$ Number of observations.

By plotting covariance (Wr) of each array against the respective variance $(\mathrm{Vr})$, information about the gene action was obtained.

Regression coefficient was calculated by the formula:

$\mathrm{b}=$ Cov. (Vr. Wr.)/ Var. Vr.

Where, 
$\mathrm{Cp}($ Covariance product $)=\sum \mathrm{XiYi}-\left(\sum \mathrm{Xi}\right)\left(\sum \mathrm{Yi}\right) / \mathrm{n}$

$\mathrm{n}-1$

$\sum \mathrm{XiYi}=$ Product of the ith array variance and covariance.

$\sum \mathrm{Xi}=$ Sum of the ith array.

$\sum \mathrm{Yi}=$ Sum of ith array covariances with parents.

Var. $(\mathrm{Vr})=\sum \mathrm{Xi}^{\underline{2}}-\sum \mathrm{Xi} / \mathrm{n}$

$$
\text { n- } 1
$$

Where,

Var. $(\mathrm{Vr})=$ Variance of the ith array variances.

$\sum \mathrm{Xi}^{2}=$ Sum of squares of ith array variances.

$\sum \mathrm{Xi}=$ Sum of the $\mathrm{ith}$ array variances.

Significance of "b" from unity was checked by t-test:

$$
\mathrm{t}=\underline{1-b}
$$

$$
\text { S. E (b) }
$$

The slope and position of the regression line fitted to the array points within parabola indicated the degree of dominance and presence of gene interaction. Regression line was drawn by plotting of covariances of each array (along y-axis) against the respective variances (along x-axis) inside parabola limits. Wri was calculated to draw regression line:

$\mathrm{Wr}=$ Mean covariance of the ith array with parents mean.

$\mathrm{Vr}=$ Mean variance of the ith array.

$\mathrm{b}=$ Regression coefficient

$\mathrm{Vri}=$ Variance of the ith array.

The points of parabola limits were computed as under:

Wrii $=\sqrt{ } \mathrm{Vp} \times$ Vri

Where,

Wrii $=$ Parabola limits.

$\mathrm{Vp}=$ Parental variance.

Vri $=$ Variance of the ith array.

The regression line touches $\mathrm{Wr}$ - axis at the point known as intercept "a" which can be estimated as under:

$\mathrm{a}=\mathrm{Wr}-\mathrm{b} . \mathrm{Vr}$

Where,

$\mathrm{Wr}=$ Covariance mean.

$\mathrm{b}=$ Regression coefficient.

$\mathrm{Vr}=$ Variance mean

The intercept provides a measure of average degree of dominance. If the regression line passes through origin (zero intercept) it shows complete dominance. If the line cuts Wr-axis above the origin (positive intercept), it shows partial dominance. If the line intercepts $\mathrm{Wr}$-axis below the origin (negative intercepts), it shows over dominance. If the regression line touches parabola limits then it point out no dominance.
Array points close to origin possess maximum number of dominant genes whereas those away from origin carry maximum number of recessive genes and the intermediate position signified the presence of both dominant and recessive genes in the

$$
S . E(b)=\frac{\sqrt{\operatorname{Var}(\operatorname{Cov})-\mathrm{b}[\operatorname{Cov}(\operatorname{Var}, W r)]}}{\operatorname{Var}(\operatorname{Var}) X(n-2)}
$$

\section{Combining ability analysis}

\section{GCA (GCA) effects:}

$\mathrm{g} 1=1 / 2 \mathrm{P}(\mathrm{Xi} .+\mathrm{X} . \mathrm{i})-1 / \mathrm{P} 2(\mathrm{X} .$.

Where,

$\mathrm{g} 1=\mathrm{GCA}$ effect for line $\mathrm{i}$.

$\mathrm{P}=$ Number of parents / varities

$\mathrm{Xi}$. = Total of mean value of $\mathrm{F}_{1}$ resulting from crossing $\mathrm{J}$ line with Ith lines.

$\mathrm{X} . \mathrm{i}=$ Total of mean value of $\mathrm{F}_{1}$ resulting from crossing $\mathrm{I}$ line with Jth lines.

$\mathrm{X} . .=$ Grand total of all means values in the table

\section{Specific combining ability (SCA) effects:}

$\mathrm{Sij}=1 / 2\left(X_{i j}+X_{j i}\right)-1 / 2 P(X i .+X . i+X j .+X . j)+1 / P 2(X .$.

Where,

Sij = Specific combining ability between Ith and Jth lines.

$\mathrm{Xij}=$ Mean value of $\mathrm{F}_{1}$ resulting from crossing the ith and $\mathrm{jth}$ lines with ith lines.

$\mathrm{Xji}=$ Mean value of $\mathrm{F}_{1}$ resulting from crossing $\mathrm{jth}$ and ith inbred.

$\mathrm{Xi} .=$ Total of mean value of $\mathrm{F}_{1}$ resulting from crossing $\mathrm{J}$ line with ith inbreds.

$\mathrm{X} . \mathrm{i}=$ Reciprocals values of Xi. 26

$\mathrm{X} . \mathrm{j}=$ Total values for the $\mathrm{F} 1$ resulting from crossing ith line with $\mathrm{jth}$ line.

$\mathrm{Xj} .=$ Values of reciprocal F1 of X.j.

$\mathrm{X} . .=$ Grand total of all means values in the table.

\section{Reciprocal effects:}

$\mathrm{rij}=1 / 2(\mathrm{ij}-\mathrm{ji})$

Where,

rij $=$ Reciprocal effects of $i$ th and $j$ th varieties (lines).

$\mathrm{Xij}=$ Mean vaues for the $\mathrm{F} 1$ resulting from crossing the ith and jth lin.

$\mathrm{Xji}=$ Reciprocal value of $\mathrm{F} 1$ resulting from $\mathrm{Xij}$.

\section{Results and discussion}

Mean data of plant character i.e. number of bolls per plant, boll weight, seed cotton yield, ginning out turn, fiber fineness, fiber length, fiber strength and seed index were analyzed using analysis of variance in RCBD (Randomized Complete Block Design) as described by 
Steel et al. ${ }^{7}$ Significant differences were present among the genotypes for all the traits. Results of analysis of variance.

The data was also subjected to joint regression analysis, for joint regression analysis mean values of four parents and each cross were arranged in $4 \times 4$ diallel analysis tables. In joint regression analysis the $b$ value must deviate significantly from zero but not from the unity for the data to be adequate for simple additive-dominance model developed by Hayman. ${ }^{6}$ Results of the joint regression analysis showed that the data for all traits were found to be adequate for simple additive-dominance model.

Values of variance and covariance were exploited to make the $\mathrm{Vr} /$ Wr graphs (Figure 1) to conclude the type of gene action and scattering of array points on the regression line. General combining ability and Specific combing ability estimates were also determined from array mean tables (Table 1).

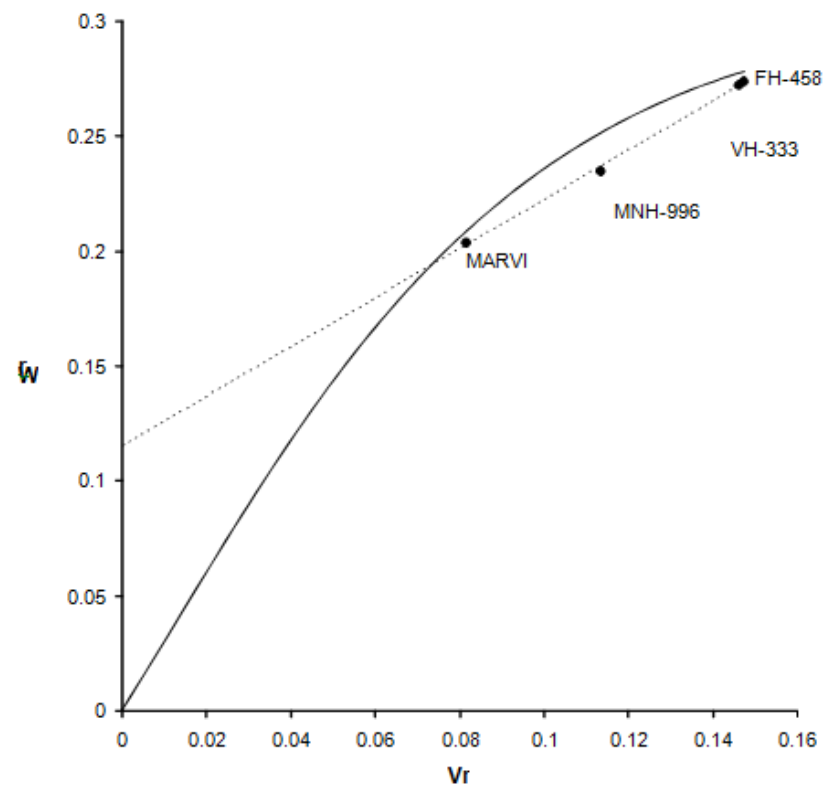

Figure I Wr./Vr. graph for fiber length.

Table I Results of joint regression analysis of six traits of cotton plant

\begin{tabular}{|c|c|c|c|c|}
\hline Sr. No. & Characters & Regression coefficient (b) & Remarks & Conclusion \\
\hline I & Fiber fineness & $0.90 \pm 0.30$ & $\begin{array}{l}\text { b value deviate significantly from zero but } \\
\text { not from unity. }\end{array}$ & $\begin{array}{l}\text { Adequate for simple additive- } \\
\text { dominance model }\end{array}$ \\
\hline 2 & Fiber length & $0.97 \pm 0.03$ & $\begin{array}{l}\text { b value deviate significantly from zero but } \\
\text { not from unity. }\end{array}$ & $\begin{array}{l}\text { Adequate for simple additive- } \\
\text { dominance model }\end{array}$ \\
\hline 3 & Fibre strength & $0.90 \pm 0.21$ & $\begin{array}{l}\text { b value deviate significantly from zero but } \\
\text { not from unity. }\end{array}$ & $\begin{array}{l}\text { Adequate for simple additive- } \\
\text { dominance model }\end{array}$ \\
\hline
\end{tabular}

\section{Fiber length (mm):}

Non significant variations were found in replication and highly significant differences were found in genotypes as shown in (Table 2a). Genotype MNH-996 exhibited more GCA effects due to maximum array mean value (25.41) as shown in (Table 2b) whereas MARVI showed least general combining ability effects with minimum array mean value (24.72). Cross MNH-996 $\times$ VH-333 showed more SCA effects with maximum array value $(26.5)$ while VH-333 $\times$ MARVI exhibited less SCA effects due to minimum array mean value (22.55).

Bolek et al. ${ }^{9}$ and Shah et al. ${ }^{10}$ were found similar results. The contradictory results were found by Hussain et al. ${ }^{11}$ and Esmail et al. ${ }^{12}$ (Table 2a-Table 2c) (Figure 1).
Table $2 \mathrm{a}$ Analysis of variance for fiber length

\begin{tabular}{lllll}
\hline $\begin{array}{l}\text { Source of } \\
\text { Variation }\end{array}$ & $\begin{array}{l}\text { Degree of } \\
\text { Freedom }\end{array}$ & $\begin{array}{l}\text { Sum of } \\
\text { Squares }\end{array}$ & $\begin{array}{l}\text { Mean } \\
\text { Squares }\end{array}$ & Fcal \\
\hline Replication & 2 & 1.0496 & 0.5248 & 1.357 N.S \\
Genotypes & 15 & 58.4537 & 3.8969 & $10.0768 * *$ \\
Error & 30 & 11.6017 & 0.3867 & \\
Total & 47 & 71.105 & & \\
\hline
\end{tabular}


Table 2b Array means table from $4 \times 4$ diallel cross in cotton (Gossypium hirsutum L.) for fiber length

\begin{tabular}{lllll}
\hline Genotypes & FH-458 & VH-333 & MNH-996 & MARVI \\
\hline FH-458 & 24.85 & 25.05 & 24.6 & 25.05 \\
VH-333 & 25.55 & 25.3 & 26.5 & 22.55 \\
MNH-996 & 24.6 & 26.5 & 25.5 & 25.55 \\
MARVI & 25.05 & 24.6 & 25.05 & 25.75 \\
Array Total & 100.05 & 101.45 & 101.65 & 98.9 \\
Array Mean & 25.01 & 25.36 & 25.41 & 24.72
\end{tabular}

Table 2c Genetic components of variation in fibre length

\begin{tabular}{ll}
\hline Components & Estimates \\
\hline $\mathrm{D}$ & 0.84 \\
$\mathrm{HI}$ & $\mathrm{I} .19$ \\
$\mathrm{H} 2$ & 0.85 \\
$\mathrm{~F}$ & -0.32 \\
h2 & 0.15 \\
(HI/D) 0.5 & 1.41 \\
$\mathrm{H} 2 / 4 \mathrm{HI}$ & 0.17 \\
(4DHI)0.5 +F/(4DHI)0.5 - F & $0.83779 \mathrm{I}$ \\
h2 n.s & 1.16 \\
h2 b.s & 0.646425 \\
\hline
\end{tabular}

Where

$D$, Variance due to additive effects; $\mathrm{H}_{1}$ and $\mathrm{H}_{2}$, variance due to dominance effects of genes; $F$, Relative frequency of dominant and the recessive alleles in the parent; $\mathrm{h}^{2}$, direction of dominance; $\left(\mathrm{H}_{1} / \mathrm{D}\right)^{0.5}$, Degree of dominance ratio or degree of dominance; $\mathrm{H}_{2} / 4 \mathrm{H}_{1}$, proportion of genes with positive and negative effects in the parents; $\left(4 \mathrm{DH}_{1}\right)^{0.5}+\mathrm{F} /\left(4 \mathrm{DH}_{1}\right)^{0.5}-\mathrm{F}$ : Proportion of dominant and recessive genes in parents; $\mathrm{h}^{2}$ n.s, Narrow sense heritability; $\mathrm{h}^{2}$ b.s, Broad sense heritability

\section{Fiber strength (g/tex)}

Non significant variations were found in replication and significant differences were found in genotypes as shown in (Table 3a). Genotype MNH-996 exhibited more GCA effects due to maximum array mean value (28.62) as shown in table (Table 3b) whereas MARVI showed least general combining ability effects with minimum array mean value (24.57). Cross VH-333 $\times$ MNH-996 showed more SCA effects with maximum array value (42.1) while MARVI $\times$ MNH-996 exhibited less SCA effects due to minimum array mean value (22.35).

Similar results were found by Ali et al. ${ }^{13}$ Karademir and Gancer ${ }^{14}$ and Batool and Khan. ${ }^{15}$ Different results were found Abbas et al. ${ }^{16}$ and Minhas et al. ${ }^{17}$ (Table 3a-Table 3c) (Figure 2).
Table 3a Analysis of variance for fiber strength

\begin{tabular}{lllll}
\hline $\begin{array}{l}\text { Source of } \\
\text { Variation }\end{array}$ & $\begin{array}{l}\text { Degree of } \\
\text { Freedom }\end{array}$ & $\begin{array}{l}\text { Sum of } \\
\text { Squares }\end{array}$ & $\begin{array}{l}\text { Mean } \\
\text { Squares }\end{array}$ & Fcal \\
\hline Replications & 2 & 1597.544 & 798.7721 & 0.9477 N.S \\
Genotypes & 15 & 38885.76 & 2592.384 & $3.0757^{*}$ \\
Error & 30 & 25285.62 & 842.8539 & \\
Total & 47 & 65768.92 & & \\
\hline
\end{tabular}

N. S, Non-significant $(P \geq 0.05)$

*, Significant $(\mathrm{P} \leq 0.05)$

**, Highly significant $(\mathrm{P} \leq 0.0 \mathrm{I})$

Table 3b Array means table from $5 \times 5$ diallel cross in cotton (Gossypium hirsutum L.) for fiber strength

\begin{tabular}{lllll}
\hline Genotypes & FH-458 & VH-333 & MNH-996 & MARVI \\
\hline FH-458 & 23.55 & 23.45 & 23.35 & 27.75 \\
VH-333 & 26.25 & 25.25 & 42.1 & 22.7 \\
MNH-996 & 24.9 & 26.25 & 26.7 & 23.6 \\
MARVI & 24.1 & 25.7 & 22.35 & 24.25 \\
Array Total & 98.8 & 100.65 & 114.5 & 98.3 \\
Array Mean & 24.7 & 25.16 & 28.62 & 24.57 \\
\hline
\end{tabular}

Table 3c Genetic components of variation in Fiber Strength

\begin{tabular}{ll}
\hline Components & Estimates \\
\hline $\mathrm{D}$ & 2.08 \\
$\mathrm{HI}$ & 2.54 \\
$\mathrm{H} 2$ & 2.3 \\
$\mathrm{~F}$ & 2.15 \\
$\mathrm{~h} 2$ & 0.3 \\
$(\mathrm{HI} / \mathrm{D}) 0.5$ & $\mathrm{I} .104$ \\
$\mathrm{H} 2 / 4 \mathrm{HI}$ & 0.22 \\
(4DHI) $0.5+\mathrm{F} /(4 \mathrm{DHI}) 0.5-\mathrm{F}$ & 2.74 \\
h2 n.s & $0.1 \mathrm{I}$ \\
h2 b.s & 0.82 \\
\hline
\end{tabular}

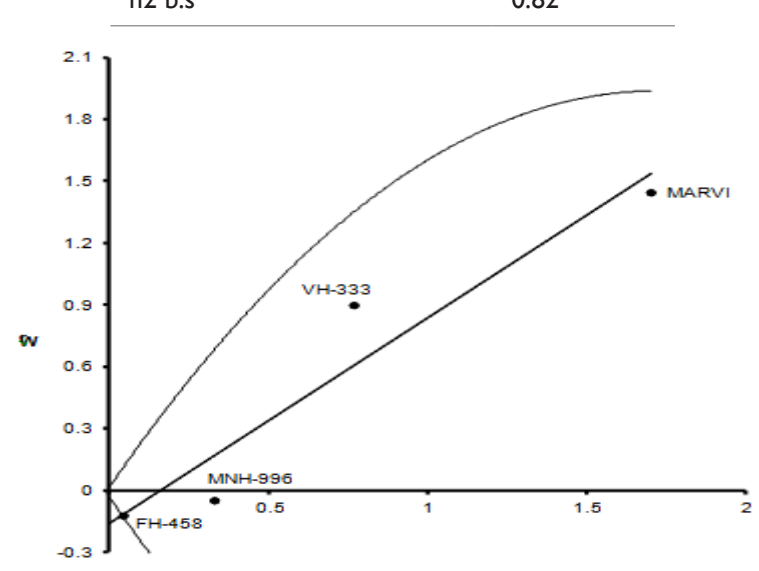

$\mathrm{Vr}$

Figure 2 Wr./Vr. graph for Fibre Strength. 


\section{Fiber fineness ( $\mu \mathrm{g} / \mathrm{inch})$}

Significant variations were found in replication and significant differences were found in genotypes as shown in (Table 4a). Genotype MARVI exhibited more GCA effects due to maximum array mean value (26.05) as shown in (Table 4b) whereas VH-333 showed least general combining ability effects with minimum array mean value (25.25). Cross MNH-996 $\times$ MARVI showed more SCA effects with maximum array value $(28.35)$ while MARVI $\times$ VH-333 exhibited less SCA effects due to minimum array mean value (24).

Similar results were found by Ali et al. ${ }^{18}$ Singh et al. ${ }^{19}$ Batool and $\mathrm{Khan}^{14}$ and javaid et al. (2014). Conflicting results were found by Aguiar et al. ${ }^{20}$ Cambell et al. ${ }^{21}$ and Minhas et al. ${ }^{17}$ (Table 4a- Table 4c) (Figure 3). ${ }^{22-35}$

Table $4 a$ Analysis of variance for fibre fineness

\begin{tabular}{lllll}
\hline $\begin{array}{l}\text { Source of } \\
\text { Variation }\end{array}$ & $\begin{array}{l}\text { Degree of } \\
\text { Freedom }\end{array}$ & $\begin{array}{l}\text { Sum of } \\
\text { Squares }\end{array}$ & $\begin{array}{l}\text { Mean } \\
\text { Squares }\end{array}$ & Fcal \\
\hline Replications & 2 & 0.4062 & 0.2031 & 0.2396 N.S \\
Genotypes & 15 & 87.6683 & 5.8446 & $6.8968^{*}$ \\
Error & 30 & 25.423 & 0.8474 & \\
Total & 47 & 113.4975 & & \\
\hline
\end{tabular}

N. S, Non-significant $(P \geq 0.05)$

*, Significant $(P \leq 0.05)$

**, Highly significant $(\mathrm{P} \leq 0.0 \mathrm{I})$

Table 4b Array means table from $4 \times 4$ diallel cross in cotton (Gossypium hirsutum L.) for Fibre Fineness

\begin{tabular}{lllll}
\hline Genotypes & FH-458 & VH-333 & MNH-996 & MARVI \\
\hline FH-458 & 24.9 & 25.2 & 26.25 & 28.2 \\
VH-333 & 26.5 & 25.95 & 24.85 & 23.05 \\
MNH-996 & 24.8 & 25.85 & 26.7 & 28.35 \\
MARVI & 25.6 & 24 & 25 & 24.6 \\
Array Total & 101.8 & 101 & 102.8 & 104.2 \\
Array Mean & 25.45 & 25.25 & 25.7 & 26.05 \\
\hline
\end{tabular}

Table 4c Genetic components of variation in Fiber Fineness

\begin{tabular}{ll}
\hline Components & Estimates \\
\hline $\mathrm{D}$ & 0.19 \\
$\mathrm{HI}$ & 0.63 \\
$\mathrm{H} 2$ & 0.57 \\
$\mathrm{~F}$ & 0.13 \\
$\mathrm{~h} 2$ & 0.36 \\
$(\mathrm{HI} / \mathrm{D}) 0.5$ & 1.82 \\
$\mathrm{H} 2 / 4 \mathrm{HI}$ & 0.23 \\
$(4 \mathrm{DHI}) 0.5+\mathrm{F} /(4 \mathrm{DHI}) 0.5-\mathrm{F}$ & 0.92 \\
h2 n.s & 0.16 \\
h2 b.s & 0.9 \\
\hline
\end{tabular}

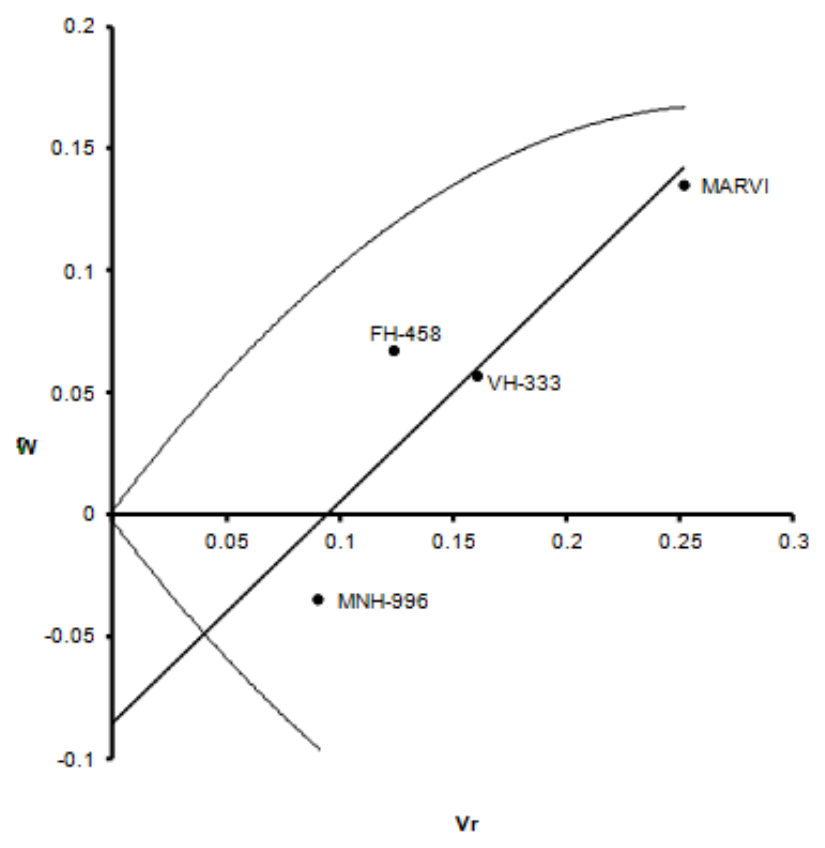

Figure $3 \mathrm{Wr}$./Vr. graph for fiber Fineness.

\section{Summary}

The objective of this study was to investigate the inheritance pattern of yield and its attributes in upland cotton by using diallel analysis Hayman and Jinks ${ }^{8}$ approach. Plant character fiber length, fiber strength and fiber fineness.

The analysis of variance (ANOVA) exhibited that all the genotypes were significantly different. Results of Joint regression analysis revealed that data of all traits was fit for additive-dominance model. Results showed that all the characters except fiber length were controlled by non-additive type of gene action following dominance and over dominance.

From the array means tables it were investigated that genotype FH-458 showed best GCA effects for fiber length. MARVI was found best general combiner for fiber fineness while VH-333 was best general combiner for fiber strength. MNH-554 showed best general combining ability for average fiber length.

\section{Acknowledgments}

None.

\section{Conflicts of interest}

Authors declare no conflict of interest exists.

\section{References}

1. Govt. of Pakistan.Economic survey of Pakistan. Finance Division, Government of Pakistan, Islamabad. 2016.

2. Memon MJ, MB Kumbhar, MJ Rind, et al. Combining ability estimates for yield and fiber quality parameters in Gossypium Hirsutum L. hybrids J BA Sci. 2016;12:53-58.

3. Javaid A, FM Azhar, IA Khan, et al. Genetic basis of some yield components in Gossypium hirsutum L Pak. J Agri Sci. 2014;51(1):143146. 
4. Ali MA, SI Awan. Inheritance pattern of seed and lint traits in cotton (Gossypium hirsutum L.). Int J Agri Biol. 2009;11:44- 48.

5. Griffing B. Concept of general and specific combining ability in relation to diallel system. Aust J Biol Sci. 1956;9: 463-494.

6. Hayman BI. The analysis of variance of diallel crosses. Biometrics. 1954;10:235-245.

7. Steel RGD, JH Torrie, DA Dickey. Principles and Procedures of Statistics. A biometrical Approach (3rded.). McGraw Hill Book International CO. New York. 1997.

8. Jinks JL. Analysis of continuous variation in diallel crosseas of Nicotiana rustica. Genetics. 1954;39:767-788.

9. Bolek Y, H Cokkizgin, A Bardak. Combining ability and heterosis for fiber quality traits in cotton. J Plant Breed Seed Sci. 2011;62:3-16.

10. Shah SAS, LH Akhtar, R Minhas, et al. Genetic control of yield and yield related traits in selected upland cotton varieties of Pakistan. J Agri Sci. 2014;9(3):129-138.

11. Hussain A, FM Azhar, MA Ali, et al. Genetic studies of fiber quality characters in upland cotton. J Anim Plant Sci. 2010;20: 234-238.

12. Esmail RM. Genetic analysis of yield and its contributing traits in two intra-specific cotton crosses. J Applied Sci Res. 2019;3(12):2075-2080.

13. Ali MA, MF Bhatti, A Abbas, et al. Assessment of inheritance pattern of some multigenic characters in cotton (Gossypium hirsutum L.). J Agri Res. 2010;48:25-33.

14. Karademir E, O Gencer. Combining ability and heterosis for yield and fiber quality properties in cotton (Gossypium hirsutum L.) obtained by half diallel mating design. Notulae Botanicae Horti Agrobotanici ClujNapoca. 2010;38:222-227.

15. Batool S, N Khan. Diallel studies and heritability estimates using hayman's approach in upland cotton. SABRAO J Breed Genet. 2012;44:322-338.

16. Abbas A, MA Ali, TM Khan. Studies on gene effects of seed cotton yield and its attributes in five American cotton cultivars. J Agri Soc Sci. 2008;4:147-152.

17. Minhas R, IA Khan, MS Anjum. Genetics of some fiber quality traits among interspecific crosses of American cotton (Gossypium hirsutum L.) Int J Agri Biol. 2008;10(2):196-200.

18. Ali MA, IA Khan, SI Awan, et al. Genetics of fiber quality traits in cotton (Gossypium hirsutum L.). Aust J Crop Sci. 2008;2:10-17.

19. Singh S, VV Singh, AD Choudhary. Combining ability estimates for oil content, yield components and fiber quality traits in cotton (Gossypium hirsutum L.) using an $8 \times 8$ diallel mating design. J Tropical Subtropical Agroeco. 2010;12:161-166.

20. Aguiar DPA, JCV Penna, EC Freire, et al. Diallel analysis of upland cotton cultivars. Crop Breed Appl. Biotechnol. 2007;7:353-359.
21. Campbell BT, DT Bowman, DB Weaver. Heterotic effects in top crosses of modern and obsolete cotton cultivars. Crop Sci. Society of America. 2007;48(2): 593-600.

22. Akhtar MM, FM Azhar, Z Ali. Genetic basis of fiber quality attributes in upland cotton (Gossypium hirsutum L.) germplasm. In J Agri Bio. 2008;10(2):217-220.

23. Ahmad A, A Ali, M Zubair, et al. Mode of gene action controlling seed cotton yield and various components in Gossypium hirsutum L. Pakistan J Agri Sci. 2001;38:3-4.

24. Ali B, MS Iqbal MK, N Shah, et al. Genetic analysis for various traits in Gossypium hirsutum L. Pakistan. J Agri Res. 2011;24: 8-13.

25. Ali MA, IA Khan. Assesment of genetic variation and inheritance mode of some metric traits in cotton (Gossypium hirsutum L.) J Agri Socio Sci. 2007;4:112-116.

26. Ali MA, AAbbas, M Younas, et al. Genetic basis of some quantitative traits in upland cotton (Gossypium hirsutum L.). Plant Omics J. 2009;2:91-97.

27. Ali I, A Shakeel, A Saeed, W, et al. Combining ability analysis and heterotic studies for within-boll yield components and fibre quality in cotton. J Anim Plant Sci. 2016;26:156-162.

28. Alkuddsi YA, MR G Rao, SS Pati, et al. Combining ability analysis for seed cotton yield (Kapas yield) and its components in intra hirsutum hybrids and forming heterotic boxes for exploitation in cotton. Genomics and Applied Biology. 2013;4:35-49.

29. Baloch MJ, JA Solangi, WA Jatoi, et al. Heterosis and specific combining ability estimates for assessing potential crosses to develop. 2014.

30. Batool S, NU Khan, S Gul, et al. Genetic analysis for yield and yield contributing variables in upland cotton. J Food Agri Environ. 2013;11:624-630

31. Bolek Y, H Cokkizgin, A Bardak. Genetic analysis of fiber traits in cotton. KSU J Nat Sci. 2014;17(1):15-20.

32. Iqbal M, Naeem M, Rizwan M, et al. Studies of genetic variation for yield related traits in upland cotton. 2013.

33. Islam MK, Akhteruzzaman, Farid U. Hetrosis test and estimation of general and specific combining ability of the crossed cotton genotype. A. Res. Rep. Cotton Development Board, Ministry of Agriculture, Bangladesh. 2014;83-96.

34. Joshi HJ, PK Chovatia, DR Mehta. Genetic variability, character association and component analysis in upland cotton. Ind J Agric Res. 2006;40(4):302-305.

35. Shah KA, NU Khan, L Shah, et al. Heterotic studies in $8 \times 8$ diallel crosses of upland cotton. Acad Res J Agri Sci Res. 2015;3(6): 128-136. 